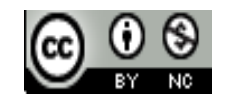

Journal of Education, Teaching, and Learning is licensed under

A Creative Commons Attribution-Non Commercial 4.0 International License.

\title{
QUALITY MANAgEMENT OF EdUCATIONAL SERVICE (CASE Study of ACADEMIC Service on SAMbas 1 State SENIOR HIGH SCHOOL (SMAN 1 SAMBAS))
}

\author{
Lisa Yuniza, Sukmawati, Muhammad Chiar \\ Universitas Tanjungpura, Pontianak, Indonesia \\ E-mail: lisayuniza.83@gmail.com
}

\begin{abstract}
This study aims to identify and analyze the form of quality management education services at SMAN 1 Sambas. This study applies a qualitative approach that uses descriptive methods. The process of analyzing data through four stages were data collection, data reduction, data presentation, and conclusion. Based on the research that has been done, the following results are obtained. (1) The quality planning of education services carried out in SMAN 1 Sambas involves various parties so that they reflect and hope that they want; (2) The implementation of the quality of educational services carried out in SMAN 1 Sambas involves the school in finding solutions to overcome the problems that occur; (3) Quality control of educational services carried out at SMAN 1 Sambas is carried out through the division of teaching tasks and follow-up on evaluation results; (4) Follow-up on the quality of education services carried out in SMAN 1 Sambas through evaluation of school programs and analysis of evaluation of learning outcomes and (5) Supporting factors and barriers to the quality of educational services in SMAN 1 Sambas based on existing facilities and infrastructure in school. Therefore, it can be concluded that the quality management of education services at SMAN 1 Sambas is running well.
\end{abstract}

Keywords: Quality Management; Educational Service; Academic Service

\section{INTRODUCTION}

The quality of education is one of the main pillars of education development in Indonesia. Quality education will produce intelligent and competitive human resources. The quality of education is closely related to the education process. Without a quality education service process, it is not possible to obtain quality service products.

Many factors cause the low quality of education, including the process of providing education services, which are still far from expectations. On the one hand, the provision of educational services has not found the most appropriate way, on the other hand, the rapid development of science and technology and the increasing life of the people and the demands of the social needs of the community as education customers. Quality education services are the provision of educational services in schools that can provide satisfaction to students in schools and communities or parents of students. School education services are the role of the school committee together with the school.

Increasing in quality of national education was a necessity for the implementation of constitutional functions. The national education system in educating the life of the nation. However, efforts to improve the quality of education are a task that is not easy because it is influenced by many factors, for this reason, it is necessary to try various ways so that the quality of our education increases. Various factors are indeed realized can influence the formation of these qualities, for example, instrumental input, teaching and learning processes, infrastructure, student-teacher ratios, adequate libraries, and so on. One effort that can be implemented is to pay attention to the school itself as an institutional system. Efforts to improve the quality of education can be sought by looking at and improving the management system of the schools concerned. The assumption is that effective school management will affect the achievement of the quality of education in the school concerned. An efficient and effective school management system has a tendency to good quality education and vice versa.

The existence of school committees is strengthened from the juridical aspect, namely Law Number 20 of 2003 concerning the National Education System, Article 56 states that: "School committees/madrasas, as independent institutions, are formed and play a role in providing quality 
education services by giving consideration, direction and support energy, facilities and infrastructure, and education supervision at the education unit level ".

Through the education quality management service paradigm, schools are given the widest opportunity to manage and regulate the implementation of education in each school, with such conditions, school committees are expected to carry out their roles and functions as support in the implementation of the learning process that is in line with conditions and problems the environment of each school. The school committee carries out its role and function as a partner of the school principal, to manage various existing educational resources in order to carry out management and improvement of the quality of education, provide facilities and support for teachers and students so that learning becomes effective.

The concept of managing quality management in school education services is a goal that must be achieved. Therefore all school resources must be managed in such a way that is directed and integrated in accordance with the functions of each school as Moenir (2015: 175) Management is a lead function and also must be responsible for carrying out the work. Thus in quality management principles, namely, "customer, leadership, the involvement of all people, the approach to the system approach to management and cooperation are mutually beneficial" (Martinus, 2016: 27).

In implementing quality management education services are always required to learn and get new information about education and improving the quality of education in getting information and applying new ideas at school, to carry out reforms in line with changing society and the times. For this purpose, various learning resources are needed for teachers and principals in developing effective, efficient, independent, productive, and accountable schools.

According to Jones (Hadith, 2014: 5) said that "teachers are determinants of the quality of education must have management skills in schools and must play a role as bearers of learning the culture." Teachers are the dominant microdeterminant component of the quality of education must be of high quality and perform well in the era of globalization by trying to master various information and communication technologies, because one aspect that experienced a tremendous change in the era of globalization. Of course, this is strongly supported by the role of the principal as a leader in running school programs that are able to provide quality education services to students.

Professional principals in enhancing the new paradigm of education management must focus on customers through improving the quality of learning and the quality of graduation, improving the qualifications of education personnel and encouraging students to pursue higher education. Quality management of education services is carried out in phases through a maximum process and effort, of course, with the existence of a principal who always pays attention to improving the quality of the school he leads by encouraging teachers and staff and the school community to achieve that quality. In addition, the principal must also pay attention to the right strategies and increased efforts to achieve the planned quality.

SMAN 1 Sambas located on Jalan Akhmad Sood No 68 Tumuk Manggis, Sambas District, Sambas Regency, West Kalimantan Province was the first Public School in Sambas District which was established in 1957 and always had good achievements, both in the field of achievement academic and achievement in non-academic fields. The interest of the community towards the school is very high considering that the school is one of the schools that have very many achievements plus this school is trusted by the Ministry of Education and Culture as a Referral School in Sambas Regency since 2016 until now, this is not easy to achieve, in this case, the school have categories, namely: (1) Schools that have been accredited A (2) Have implemented the K13 curriculum (3) The school has a recommendation from Sambas District Education and Culture Office and schools in the Regency. Sambas, (4) For 3 consecutive years since $2012 / 2013$ to $2015 / 2016$ it has always been ranked number 1 on the results of the National Examination in Sambas for both public and private schools, both at the sub-rayon level and at the Rayon level, besides that this school is in the middle of the city and is very strategic to visit.

In addition to the above output from the SMAN 1 Sambas, it also dominated the leading universities in the province and outside the province of West Kalimantan and even abroad, besides the various achievements achieved by the school. Various efforts have been made to manage the quality education services in the SMAN 1 Sambas, among others through various training and increasing teacher competencies, procurement of books and learning tools, improvement of educational facilities and infrastructure, and at the same time improving the quality of education in schools. This kind of achievement and effort is certainly inseparable from the management of the school, both from the concept of a comprehensive management strategy, which should look at the goals, policies and action plans as an inseparable entity and its implementation is dynamic. For this reason, management plays an important role in determining the planning and actions that must be taken by the school.

Functionally, education is basically aimed at preparing people to face the future so that life is more prosperous, both as individuals and collectively as citizens of the community, nation, and between nations. But now our education world is not fully able to meet the expectations of society. This phenomenon is characterized by the low quality of graduates, resolution of educational problems that are not complete, or tend to be patchy, even more, oriented on the project. As a result, often, educational outcomes disappoint the community. They continue to question the relevance of education to the needs of the community in the dynamics of economic, political, social, and cultural life.

Management of schools by providing greater authority at the school level to manage their own schools directly, with the existence of such a large authority, the school has the autonomy, responsibility, and participation in determining school programs. In implementing quality management services, education is always required to learn and get new 
information about education and improving the quality of education in getting information and applying new ideas at school. To be able to provide satisfactory services for service delivery, they must fulfill service principles, namely, transparent (open) so that it is easy and accessible to all parties who need it and can be accounted for according to the provisions (Ratminto \& Winarsih, 2016: 20).

Thus management of education quality is a method of improving the quality of education, which is a method of improving quality based on the institution. SMAN 1 Sambas by applying a set of techniques, based on the availability of qualitative data and the empowerment of all components of the SMAN 1 Sambas to continuously increase the capacity of the school's capacity to meet the needs of students and the community. Effectiveness in the pattern of implementation of quality management, implementation, and planning are outlined in the Vision, Mission, and school objectives of SMAN 1 Sambas.

All resources owned by the school can be organized directly by the school, which is then carried out comprehensively by all elements of the school and ultimately produces excellent output. The part of management strategy and integrated quality in managing schools is inseparable from the strategy of managing the education system as a whole and is oriented towards efforts to improve quality. In this case, SMAN 1 Sambas is a high school and produces graduates who are able to compete with other schools, so education development is oriented to the quality assurance system.

Management of education staff in schools that utilize educational staff effectively and efficiently in order to achieve optimal results, but still in pleasant conditions, it is necessary to have competence. Pedagogic competence is the ability to manage student learning, which includes an understanding of students, planning, and implementing learning, evaluating learning outcomes, and developing students to actualize their various potentials. Personality competency is a strong, stable, mature, wise, and authoritative personality ability, being an example for students and having a noble character. Professional competency is the ability to master the material widely and deeply, which enables it to guide students to meet the competency standards set out in the National Education Standards.

Based on the above background and note that the effectiveness of SMAN 1 Sambas is one of the most important factors in effectively driving school development, especially in implementing standardized process teachers always provide examples, build willingness and develop potential and creativity in the learning process. The leadership of the principal must be able to master management in providing quality education services so as to be able to succeed in programs rolled out by the government, especially in meeting national education standards. Through a survey conducted by researchers that the SMAN 1 Sambas was established in 1957 with only 50 students so that until now the number of students has increased. Considering the quality of education is very important, the principal as the school leader and the teacher boards are able to develop the school both from the professional development of educators and education, preparation of facilities and infrastructure to the satisfaction of educational services, therefore the authors are interested in conducting research with the title "Quality Management of Educational Services at SMAN 1 Sambas".

\section{MEthodology}

The approach used in this study is a qualitative approach that uses descriptive methods. The use of qualitative research methods is used because researchers want to express the symptoms in full and describe the actual situation of a problem in the research, how is the quality management of education services in SMAN 1 Sambas.

The qualitative approach in this study is used to describe the quality management of education services at SMAN 1 Sambas, which refers to service quality planning, service quality implementation, service quality control, follow-up service quality and inhibiting factors and service quality support. For this reason, the researcher conducted a series of activities in the field, starting from visiting the location, orientation study, and continued with a focused study.

The location study of the researchers conducted on March 1,2019 , namely introducing themselves to the principal as the leader and delivering the results of the research proposal seminar that had been carried out as well as submitting a letter of permission from the Dean of FKIP Tanjungpura University Pontianak. After meeting with the headmaster, the researcher asked permission to document environmental conditions, buildings, learning atmosphere whereas the orientation study was conducted on March 7, 2019, by conducting meetings with school principals, vice principals, administrative officers, and teachers. For focused studies conducted on March 25, 2019, until March 30, 2019, involving principals, teachers, and administrative staff, school supervisors and students. In this study, the researcher acted as a participant observer. Thus researchers will make direct observations because it will benefit greatly.

The location of this study was conducted in the school of SMAN 1 Sambas. The researcher is present directly to the research location to collect data, process data, and check the validity of the data. The researcher conducted direct interviews with key informants, namely, principals, teachers, employees, and students. The researcher also visited the administration to look for documents relating to the quality management of education services. This document is used as a comparison of the results of interviews with resource persons, both principals, teachers, students, and students.

The source of data extracted in this study consists of the main data sources in the form of words or actions, as well as additional data sources in the form of documents. The sources of this research data are principals, teachers, business staff, employees, and students. This source was chosen because it has a direct relationship and supports the research carried out. The type of data needed in this study comes from primary data and secondary data. The source of primary data is obtained through interviews with principals, administration, students, and students while secondary data 
sources in the form of supporting documents in this study, for example, the profile of the school of SMAN 1 Sambas, reference books, and relevant research reports.

Data collection techniques used in this study are interviews, observations, and documents. The interview used in this study was in-depth interviews. This method is carried out in a structured manner with the aim of obtaining more indepth data about the quality of education service quality in SMAN 1 Sambas. In this study, the authors conducted interviews with principals, administration, employees, and students. Interviews were conducted by questioning about 1) education service quality management planning, 2) implementation of quality management of education services. 3) quality management control of education services, 4) follow-up management of quality education services, 5) inhibiting factors, and supporting quality management of education services. Observations made in this study are straightforward and direct to the phenomenon under study. The researcher openly explained the purpose and objectives of the research first, so that it would be easier to get the desired data. Researchers observe directly the activities or activities of principals, administration, teachers, and students during school operational hours without the help of others. The documentation method used in this study is to collect material in the form of data, archives, documentation regarding the management of quality education services in Public High School 1 Sambas Reference, school profiles and photographs relating to this research.

The documents obtained by researchers are related to the activities of planning, implementation, control, follow-up as well as supporting factors and barriers to the quality of services provided in SMAN 1 Sambas, including school profile documents, work plans and budgets, minutes of meetings, photos of activities, books student and teacher achievement records, supporting laws and regulations, minimum service standard documents, teacher and administrative performance appraisal, and follow-up plans.

Data collection tools used in this study are observation guides and interview guidelines. The observation guide is prepared based on observations of the subject's behavior during interviews and observations on the environment or interview settings, and their influence on the behavior of the subject and information that appears during the interview that relates to the quality management of education services in Sambas 1 High School. The interview guide contains a list of systematic questions and as a reference for the author to obtain data on quality management of education services in SMA Negeri 1 Referral Sambas.

The data analysis used by researchers is the model of Miles and Huberman (Sugiyono, 2011: 246-253), the data analysis technique contained in this study refers to an interactive analysis that is "the analysis process carried out simultaneously with the data collection process." This analysis process goes through four stages, namely data collection, data reduction, data presentation, and conclusion drawing. The problem of reducing data presentation data, and drawing conclusions / verification is a picture of success in sequence as a series of analysis activities that follow each other. In detail, the researcher can explain the steps in the interactive analysis model are as follows:

a. Data Reduction

Data reduction is a process by which the author makes a selection, breaking the attention to simplification, abstracting the results of the research. This process is also often said to be a data transformation process, namely the change from raw data to data that is truly ready to be used as a result of research. Data that is reduced is data obtained through interviews with principals, administration, employees, and students to be selected the main things based on the focus of the study.

b. Presentation of Data

The presentation of this data uses a descriptive presentation that is displayed with the type of direct quote, image, or chart or table. Data is presented in accordance with what is examined, the purpose of this study is limited to facilitate the author to organize data based on the focus of research.

c. Withdrawal Conclusion

First, the author conducts research in the field by conducting interviews or observations called the data collection stage. Because a lot of data is done, data reduction is done. After the data is reduced, then a data presentation is held, besides that, data collection is also used for data presentation. If all three things have been done, a conclusion or verification is taken. The process of analyzing data while reducing data to select data, in this case, simplification of existing data. Furthermore, the author will draw decisions or conclusions based on data obtained through interviews with principals, administration, employees, and students.

In this study, testing the validity of the data using the triangulation technique, which is a triangulation technique is a technique of checking the validity of data that uses something outside the data for data checking purposes. The source triangulation technique is done by checking several data sources with the same method. This data is obtained by searching for several informants with the same method. In this study, the authors checked the degree of trust of the source by interviewing different informants, namely with principals, administration, employees, and students.

Moleong (2013: 163). argues that "the implementation of the research has four stages, namely, (1). The stage before going to the field, (2). Fieldwork stage, (3). Data analysis phase, (4). Report writing stage. In this study, the steps taken are as follows:

a. The stage before going to the field

b. Stage of field work

c. Data analysis phase

d. Report writing stage

\section{RESULTS AND DISCUSSION}

\section{A. Results}

The activity of collecting data on management of quality of education services in SMAN 1 Sambas was carried out by 
the researchers themselves. The researcher did not conduct an interview based on the level of position in the school, but followed the scheduling of the vice principal of the field of public relations namely Ms. Hasibah, S.Pd about time, place and resource person or informant regarding key information, namely the Head of SMAN 1 Sambas which in April had a lot of activities official service, so for the sake of fluency he arranged the interview scheduled to be held.

Field observations by taking photos of locations, photos of activities, and objects related to the quality management of educational services at SMAN 1 Sambas are also carried out every time after the interview. The same opportunity is also used by researchers to request the necessary documents so that one day get various information needed in the study. Researchers make use of each free time to type transcripts of interviews, analyze them and revisit the data interviewees interviewed to ensure that the intent of the answers given is as stated in the transcript of the interview results. After reviewing the transcript of the interview, there were parts of the answer he added, especially when answering the question of the mission and objectives of SMAN 1 Sambas, which had been set by the school.

1. Quality Education Service Planning

Everything that is done with good planning will support the achievement of common goals. With the planning, all parts can carry out their activities in a directed and measurable manner because they have clear guidelines. Quality management of educational services provided to study residents and outsiders. The form of education service quality management planning in SMAN 1 Sambas includes (1) Vision and Mission, (2) Work Program, (3) Preparation of Syllabus and RPP and (4) Preparation of teaching materials. The results of interviews, observations, and documentation in the aspects of education service quality management planning obtained data as follows:

a. Interview result

Data obtained from interviews with principals, deputy headmasters in the field of public relations, deputy head of the curriculum in the field, deputy head of facilities and infrastructure, deputy head of the student section, head of the referral school coordinator, head of the school committee, two students and duan parents of students regarding education service quality management planning in SMAN 1 Sambas is like the original summary of the following interview:

1) School Vision and Mission

The School Vision and Mission is a benchmark that must be and must be designed by the principal and socialized. The vision and mission is the agreement of the school community through a committee team formed by the school principal to prepare a vision and mission idea from the principal. Ideas or plans arise by looking at the situations and conditions that exist in the school so that the school's vision and mission are published. The school's vision and mission must be changed as the headmaster changes as long as there are developmental demands from time to time. It has been 4 years now that the vision and mission carried out in SMA 1 until now are still very suitable and relevant to the development of schools, specifically about planned school management.

All educators and non-educators in the school environment must socialize the vision and mission without stopping. Its implementation to school residents is a matter that really needs hard work because the vision and mission designed are not only used as displays in front of the school. Pamphlets or banners are displayed in every corner of the school both small and large sizes, delivery and application are carried out in the classroom and outside the classroom that is when the apple is required every Monday.

2) School Work Program

SMAN 1 Sambas has a long-term and shortterm school work program, long term is made every 4 years once, while for the short term once every year will enter the new school year. The school work program is made based on the condition of the school, each vice principal, coordinator and homeroom teacher is required to make a school work program that will be discussed and agreed upon together in a meeting with the entire board of teachers and will be endorsed by the principal with the school committee. This shows that principals are democratic and give trust to teachers to contribute positively from the start of planning.

3) Preparation of the Syllabus

All teachers in SMAN 1 Sambas are required to make syllabus, the preparation of syllabus is usually carried out in an activity together, namely IHT activities for several days. The syllabus arrangement is carried out at the beginning of the new school year and during out-of-school hours so that it does not interfere with teaching and learning activities at school.

4) Preparation of RPP

RPP preparation activities in SMAN 1 Sambas were carried out in one activity during the preparation of the syllabus simultaneously, namely in the IHT activities. In these activities, each teacher is grouped according to the subjects taught. RPP preparation activities are always accompanied by the principal, all teachers coordinate with the deputy headmaster in the curriculum field so that the RPP is made more coordinated according to the planning that has been made and the activity can be resolved to the maximum

5) Preparation of Teaching Materials

In the preparation of teaching materials in SMAN 1 Sambas, all teachers are required to create teaching materials, some of the teachers 
who have taught in the school have written teaching materials in e-modules, teaching materials made based on curriculum 13 that have long been applied in SMAN 1 Sambas.

b. Documentation results

Documentation in planning activities is intended to obtain data or evidence of planning activities in the form of documents, pictures, or photos of activities. Documentation in education service quality management planning activities obtained by researchers included photos of the preparation of the Vision, Mission and School objectives, photos Socialization of vision and mission to parents of students, photos in the preparation of syllabus and lesson plans for IHT activities, work program documents, curriculum documents 2013 SMAN 1 Sambas, as well as context analysis documents that have been prepared.

2. Implementation of Quality of Educational Services

Good planning will not be useful if it is not actualized. The implementation of education service quality management activities includes the involvement of all parties, the involvement of all teachers, student involvement, the involvement of parents, the involvement of school committees and involvement of the local government, especially the department that handles education.

a. Interview result

The results of the interviews were conducted with the principal, deputy head of the public relations field, deputy head of the curriculum in the field, deputy head of facilities and infrastructure, deputy head of the student section, head of the referral school coordinator, head of the school committee, two students and parents of students regarding the implementation of quality education service management in SMAN 1 Sambas is like a summary of the following interview results:

1) Involvement of the Principal

All educators and non-educators are involved in the team to improve the quality of services provided. Collaboration is well established between schools, study residents, school committees, and parents. The role of the principal is very large where he will always monitor the progress of the implementation of the school program that is run every 1 month, 3 months and the first 6 months, if there are problems it will be revised at the end of the year. Problems that arise will be discussed together at the end of the school year, in order to find the best solution to the problems obtained. The results of the evaluation will be used as material for the preparation of work programs the following year.

2) Teacher and staff involvement

In implementing the school program planning that will be carried out, teacher involvement is the spearhead in the success of the program that has been planned previously. So that their involvement is an important thing to pay attention to by the school. So that the goals you want to achieve can run smoothly.

3) Student involvement

The data source interviewed provided information that the services provided by the school were inseparable from student involvement because good cooperation between the school and the learning community was very much needed so that what the school planned would be done well if the learning citizens also supported. So that what is aspired together will be achieved for the common good too.

4) Involvement of School Committees and Parents

SMAN 1 Sambas has a school committee that is very supportive of every school program that will be implemented, excellent coordination is the main key in terms of their collaboration. This is very influential on every funding that will be issued by the school. Usually, every activity that cannot be covered by the school, the committee in its implementation will assist the school in terms of funding, especially activities that directly support the citizens of their study.

b. Observation results

Observations are carried out by researchers to obtain real data from the location of the study so that the actual situation is known with the intention that the data presented can be justified according to the facts. The results of the observations made by the researchers obtained an overview of the interactive situation between the students learning from the teachers, principals, and staff in the school, and found a familiar situation between the teacher and parents of students who came to school for certain purposes.

During the first break visit at 09.35 , the researcher saw 5 students who were in the school hall, talking to a teacher. This shows that the services provided by the school are very good and a comfortable and family atmosphere.

The next observation the researchers monitored from outside the school, from a distance the researcher obtained a picture of the school community preparing for the Monday rally, the researchers saw student order very visible in the eyes, when the ceremonial instructor gave direction, the coach always reminded the students and all those present to keep the vision and the school's mission to be applied in their daily lives, both within the school and outside the school. After the morning applause, all the learning residents and teachers greet each other. The familiarity of the school with the learning community is very visible and exemplary by every school.

c. Documentation

Data document implementation of quality management education services can be seen from 
documents for external and inner conditions of learning, photos of students who are familiar talking with teachers, as well as photos during learning in class, interactions between teachers and learning citizens are very active.

3. Education Service Quality Control

The controlling aspect includes who are the parties involved in the control, namely control techniques or procedures and follow-up controls. The results of interviews, observation, and documentation in the aspects of management of quality education service management in SMAN 1 Sambas obtained data as follows:

a. Interview result

Data obtained from interviews with principals, deputy school principals in facilities and infrastructure, deputy head of curriculum in the field, deputy headmaster of student affairs, deputy headmaster of community relations, head of the school committee and head of the referral school coordinator regarding education service quality management. in SMAN 1 Sambas is like a summary of the following interview results:

1) Supervisory officer

Information is obtained that principals conduct periodic quality control services based on reports from each vice principal, and occasionally conduct direct inspections at student service activities, for example, in the library room and computer laboratory room. The deputy head of the public relations and infrastructure section also conducts regular supervision based on reports from the coordinator of each room in the school environment.

2) Division of teacher teaching tasks

Division of assignments and hours of teaching at SMAN 1 Sambas will be discussed and discussed together at the beginning of the new school year. The division of teaching assignments in SMAN 1 Sambas is based on the competencies of each teacher. The division of tasks and hours of teaching is a decision or policy of the principal.

b. Observation results

Based on the results of observations on aspects of control that principals play an important role in terms of controlling the quality of services provided to teachers, learning residents, parents and outside parties as well as the local government.

\section{Follow-Up Quality Management of Education Services}

In connection with the follow-up of the results of supervision, interviews with the data sources inform as follows:

a. Interview result

Follow-up on the results of the evaluation of the learning community is included in the daily test results, semester tests, and end of semester tests. How to deliver it as follows:
1) School Program Evaluation

Follow-up after evaluation, if the program does not show improvement in the quality of services provided, the program will be eliminated in the future. Evaluation of the work program always coordinates with the headmaster, discussed and concluded so that the principal can take the policy on the existing problems.

2) Evaluate the results of the learning process

All teachers at SMAN 1 Sambas carry out an evaluation of the learning process. Evaluation analysis of learning outcomes is carried out at the end of the semester. Evaluation analysis of the results of the learning process is carried out not only based on repetition values but daily results, short-term and long-term projects (student assignments) and daily student behavior and student motor skills. The results of the evaluation of the learning process are contained in e report cards. School steps for future quality improvement at all times are carried out in all fields, including services provided by schools to study residents, parents, local government, and other external parties. Schools will continue to improve the academic and non-academic values of graduates every year.

b. Documentation Results

Documentation obtained from the supervision process in the form of photos of service activities, inspection photos to the library, photo reporting program. Documentation of activities can be seen on the attachment page.

5. Supporting Factors and Barriers to Education Service Quality Management

Obstacles or constraints are almost always in every activity, both those with mild constraints and not disturbing the achievement of goals, or that can hinder the effectiveness of achieving goals. Detecting and expressing obstacles in an activity is not just to complain that results in a decrease in motivation, but as part of the results of self-evaluation to improve and correct the deficiencies. On the contrary, with supporting factors, instead, we can get away with the existing support. On the contrary, we still have to maintain the support that we have achieved. Can at least maintain it.

a. Interview result

Data obtained from interviews with principals, deputy school principals in facilities and infrastructure, deputy head of the curriculum in the field, deputy head of the student field, deputy head of the community relations field, head of the school committee and chair of the school coordinator for supporting factors and barriers in the management of quality education services at SMAN 1 Sambas is like a summary of the following interviews:

Information about the number of students is a supporting factor in improving the quality of services 
provided to residents of learning and external parties because with a large number of students can make it easier to get facilities and infrastructure both government assistance and from students / parents through school committees to support increased activities and teaching and learning process at school. Supporting factors in improving the quality of services provided are good cooperation from all parties involved (schools, study residents, government, parents, and school committees). Factors supporting the existence of facilities and infrastructure owned by the school have almost all been fulfilled. All big or small obstacles must all be there, but just how we react to them as principals must be wise.

Information also obtained from the head of the school committee stated that the supporting factors for the facilities and infrastructure owned by the school were almost all fulfilled. There is still a shortage of teachers in a number of subjects so that the deputy headmaster is still a double job if he gets an assignment out by the principal. The victims are students who should study with the teacher, they are only given assignments in the classroom.

Facilities and infrastructure in schools are almost $90 \%$ fulfilled, schools continue to improve, add to existing facilities in schools. Learning in schools is mostly already using a projector. Comfortable classrooms, making us learners feel at home learning in class."

School services provided by the school are adequate; each classroom is equipped with a projector. students are given the freedom to determine extracurricular activities to be participated in, extracurricular activities offered at school include scout, paskribraka, pencak silat, basketball, volleyball, soccer, karate, sispala, and others.

The rules and regulations that apply to SMAN 1 Sambas are very, very educating students always to be obedient students and feel that the rules that have been made are not a burden for them to run, but to be run sincerely.

b. Observation results

The results of direct observation in the field found obstacles in the form of facilities and infrastructure, where obstacles arose from existing infrastructure, for example, the available focus units were 10 units, while the classes that needed were 20 classes, so when they were to be used they had to wait for the other classes to finish. In addition, the existing projector is damaged because of its long usage period, sometimes it will be damaged when it will be used.

\section{B. Discussion}

1. Quality Planning for Educational Services in SMAN 1 Sambas

The plan is a desire or hope to be achieved in the future and used as a guideline. The process for producing a plan is called planning. In achieving the goals to be achieved, then there needs to be planning in improving the quality of education. Planning functions as "the process of drafting various decisions that will be carried out in the future to achieve the stated goals (Asmara, 2017: 6). In educational institutions, the desires and hopes that will be achieved are called School Vision. Therefore, the initial question that the researcher conveyed to the principal related to planning was the school's vision.

The vision, mission, and goals of the school are the strategic plans of the school, prepared by the principal, vice principal, teacher, administration, school committee, students, parents of students and the community. There are seven steps of objective management developed in developing a strategic plan, (2015 UPI Lecturer Team in Supriyanto, 2016: 55)

Regarding the quality of education service planning in SMAN 1 Sambas, researchers asked about the school vision document, which was the basic guideline, the principal, Mr. H. Edy Kiswar, S.Pd. It can be concluded that the School Mission Vision is a benchmark that must be designed by principals and socialized. The vision and mission are the agreement of the school community through a committee team formed by the school principal to prepare a vision and mission idea from the principal. Its implementation to the school community is something that requires hard work done through the distribution of pamphlets or banners in every corner of the school both small and large sizes, delivery and application carried out in the classroom and outside the classroom when the apples are required every Monday, besides the teacher council participation in the working meeting, making annual program, semester program, syllabus and LESSON PLAN and teaching materials which will be corrected by the principal.

Furthermore, regarding the quality of education service planning in SMAN 1 Sambas, the researcher asked about the school's vision which became its basic guideline, $\mathrm{Mr}$. H. Sunardi as the deputy head of the school for facilities and infrastructure stated that Planning the school's vision and mission was made through meetings with the board both civil servants and non civil servants and agreed upon so that the implementation is more directed. The way to convey the vision and mission besides the flag ceremony was also conveyed at the start of the lesson. Students are always reminded to remain obedient and carry out their duties as citizens in SMAN 1 Sambas.

The school vision is a representation of the wishes and expectations of parents in sending their children to school and fulfilling the wishes and expectations of other stakeholders. Vision will be realized well if there are good planning and the active role of all school parties. Indicators developed by the school are implementing the expectations of parents of students to be able to compete so that they have achievements to the level of college.

Vision is the ideal picture for the future desired by the school. This vision provides insight into the source of direction for schools and is used to guide the formulation of school missions. Vision is the foresight where the 
school will be brought. The future picture must be based on a juridical foundation, namely laws, government regulations, ministerial regulations, and other regulations in accordance with the level and type of school.

School vision must remain within the framework of national education policy but in accordance with the needs of the school for community service. With the aim of national education whose formulation is the same, the profile of the school and the needs of the community served by the school are not always the same. Therefore, schools have a vision that is not the same as other schools, provided that they do not come out of the corridors of the national education goals.

Interview with Mr. Sukarsono, S.Pd as deputy head of the curriculum in the education service quality planning at SMAN 1 Sambas, in addition to the school vision described above, he also stated that there was a need for school work meetings. The making of a school work program is brought together by all the teacher councils in the school and the school committee. This is done to adjust the budget that will be issued in each activity, in addition to the preparation of the annual program, a semester program, syllabus, and RPP that must be made by all teachers.

Work meetings are a benchmark in drawing up a work program design for both the principal and the board of teachers and other school staff. Especially the teacher council to be easier in formulating various school administrations such as Syllabus and RPP.

The syllabus is a learning plan for a particular subject and / or group / theme which includes competency standards, basic competencies, subject matter / learning, learning activities, competency achievement indicators for assessment, assessment, time allocation, and learning resources. The syllabus is a set of plans and arrangements for the implementation of learning and assessment that are systematically arranged which contain interrelated components to achieve mastery of basic competencies.

The syllabus is useful as a guideline for developing further learning devices, starting from planning, managing learning activities, and developing assessments. The syllabus is useful as a guideline in the development of further learning, such as making learning plans, managing learning activities, and developing assessment systems. The syllabus is the main source in preparing learning plans, in addition to learning plans for one Competency Standard and one Basic Competency.

The syllabus is also useful as a guide for planning management of learning activities, such as classical learning activities, small groups, or individual learning. Similarly, the syllabus is very useful for developing a scoring system.

The learning implementation plan (RPP) is a plan that describes the procedures and organization of learning to achieve a basic competency set out in the Content Standard and described in the syllabus. The objectives of the learning implementation plan are to: (1) facilitate, facilitate and improve the results of the teaching-learning process; (2) by compiling a learning plan in a professional, systematic and efficient manner, the teacher will be able to see, observe, analyze, and predict the learning program as a logical and planned framework.

2. Implementation of Quality of Education Services in SMAN 1 Sambas

Implementation is the most important management function. The function of planning and organizing were more related to the abstract aspects of the management process, while the implementation function actually emphasizes activities that are directly related to the people in the organization. Implementation is an effort to do planning into reality, through various directives and motivations so that each work can be carried out optimally in accordance with roles, duties, and responsibilities.

The implementation of the quality of education services carried out by the principal is in accordance with the results of interviews with the Principal Mr. H. Edy Kiswar, S.Pd, which can be concluded that in implementing the quality of school education services all educators and non-educators are involved in the team to improve the quality of services provided. Good cooperation between schools, study residents, school committees, and parents of students. The principal will monitor the progress of the school program that is run every 1 month, 3 months and the first 6 months, if there are problems it will be evaluated and revised at the end of the year. Problems that arise will be discussed together at the end of the school year so that the best solution can be sought for the problems obtained. The results of the evaluation will be used as material for the preparation of work programs the following year.

The results of the interview with the headmaster were in line with the results of interviews with Ibu Sri Rahayu as Chair of the Referral School Coordinator at SMAN 1 Sambas which stated that in implementing the quality of education services was the involvement of the school team. All educators and non-educators are involved in the team to improve the quality of services provided. Good cooperation between schools, study residents, school committees, and parents of students. The program implemented is in accordance with what was made when the new school year began. The principal has an important role in monitoring progress every 3 months 1 time. Within 1 year, the work program of each vice principal will be evaluated by the principal.

In the implementation phase, each education service team has a workflow for each component that is in the implementation of the quality of education services concerned. Schools make and have guidelines that regulate various aspects of management in writing that are easy to read by the parties concerned. The formulation of school guidelines is reviewed and reformulated periodically in accordance with community development. Guidelines for school management include curriculum, educational / academic calendar, school organizational 
structure, division of tasks among teachers, division of tasks among education staff, academic regulations, school discipline, school ethics code, school operational costs.

School guidelines serve as operational implementation guidelines. Guidelines for managing the curriculum, education calendar, and division of tasks for educators and education staff are evaluated on an annual scale, while others are evaluated as needed. The school organizational structure contains the system of administration and administration, which is clearly and transparently described. All leaders, educators, and education personnel have clear job descriptions, authority, and responsibilities regarding the overall administration and administration of the school. The guideline governing the organizational structure of schools is to include elements of administrative staff with clear authority and responsibility for administering administrations optimally, evaluated periodically to see the effectiveness of school management working mechanisms, decided by the principal by considering the opinions of the school committee.

Implementation of school activities is carried out based on an annual work plan, carried out by the person in charge of activities based on the availability of available resources. The implementation of school / madrasah activities that are not in accordance with the stipulated plans needs to be approved through the board of educator and school committee meetings. The principal is responsible for the implementation of academic management at the educator board meeting and the nonacademic field at the school committee meeting in the form of a report at the end of the school year delivered before the preparation of the next annual work plan.

3. Quality Control of Educational Services in SMAN 1 Sambas

An institution in improving the quality of education needs to carry out a control function, in order to run in accordance with the established pathway and arrive at the destination effectively and efficiently. The control function aims to supervise, assess so that it does not deviate from the path. If this happens, efforts need to be made to restore it, so that it needs evaluation so that it does not happen again. Schermerhorn, (Supriyanto, 2016: 56). Control is a process to ensure that actual activities are in accordance with planned activities. An educational institution needs to carry out a control function.

The steps are taken in the control process as explained by the principal after the interview was concluded that in controlling the quality of education services in schools is necessary to do the division of tasks and teaching hours which are closed at the beginning of the new school year. The division of teaching assignments in SMAN 1 Sambas is based on the competencies of each teacher. The division of tasks and hours of teaching is a decision or policy of the principal. Follow-up on the results of the evaluation of the learning community is included in the daily test results, semester tests, and end of semester tests.
The same thing was expressed and explained by Ms. Hasibah, S.Pd as Deputy Principal of the Public Relations Division from the results of interviews conducted by researchers who stated that in controlling the quality of education services in schools it is necessary to do the division of tasks and teaching hours which are closed at the beginning of the school year new. The division of teaching assignments in SMAN 1 Sambas is based on the competencies of each teacher. The principal has an important role in regulating and dividing the schedule of each available teaching staff. Follow-up on the results of the evaluation of the learning community is included in the daily test results, semester tests, and end of semester tests. Evaluation of work programs etc. was conveyed during routine meetings held by the school.

The principal, as an education manager includes several activities, namely: teaching predictions, innovating, creating strategies or policies, making plans, finding educational resources, providing facilities, implementing. A principal from the managerial aspect is expected to function as a Middle Manager between the teacher / employee and the management of the foundation, meaning that the principal is expected to translate the ideals of the foundation board so that all the teachers / staff they lead can support and carry out their tasks so that what is the ideals of the management, can absorb, filter and formulate desires, ideas of the teacher / employee to be conveyed to the management.

In the school unit, the principal is expected to function as a leader, administrator, and supervisor. The principal as the leader has the task of planning, organizing activities, directing activities, implementing supervisors, carrying out evaluations, determining policies, making decisions, regulating the process of learning / teaching, managing administration, organizing student organizations, regulating school relations with the government and society.

The principal, as an administrator, has the task of understanding the components of education in schools and how to manage these components in order to achieve the expected education. The scope of school administration activities that should be managed by the school principal includes administration of teaching programs, student administration, personnel administration, finance, administrative equipment, libraries, student development, relations with government and society, the role of Principals in Learning Management.

The principal is the key to success in empowering the community and the school environment for that as a headmaster the school is expected to be able to try to foster, manage and develop the resources that are in the school. Leadership is important in improving educational programs, and educational leadership is an activity that facilitates the achievement of educational goals. Leadership here refers to the principal where a school principal is expected to be able to play a role and facilitate the achievement of educational goals in school. 
The task of the principal in the management of learning is to hold a curriculum book on the guidelines of general and specific books, together with the teacher to understand and describe the goals of education including general goals, instructional goals, curricular goals, and specific objectives. Together with the teacher compile curricular programs and additional activities, including in this case the annual program, together with the teacher developing teaching tools, arranging schedules and division of tasks, developing learning evaluation systems, supervising process activities teaching and learning, compiling norms of class increases, developing libraries as a science and place of learning.

The principal is expected to motivate the teacher by encouraging teachers to actively work according to certain procedures and methods so that the work runs smoothly to achieve the goals. The task of motivating and activating this is more complemented by efforts to prosper the teacher, believed in providing encouraging results. Part of that welfare can be realized through motivating and activating activities.

As a learning leader, the principal is expected to be able to improve the quality of learning. leadership by the principal is characterized by careful attention to the quality of teaching. The emphasis is on how the principal conducts his activities so that the teacher can carry out his teaching with high quality. principals play an active role as teaching leaders who strive to improve teaching skill and improve student academic achievement to be high.

4. Follow-Up Quality of Education Services in SMAN 1 Sambas

One of the school supervision activities is evaluating or evaluating school programs, which are the educational evaluation of competency dimensions that school supervisors must have. All school activities, including school development plans, are outlined in the program prepared by the school. This is the basis for the reference and accountability of supervisors in their duties and functions in evaluating school programs.

To be able to evaluate the school program properly, a supervisor needs to have a comprehensive understanding of the scope of his duties, mastering the procedures for evaluating school programs, as well as the ability to think systematically to evaluate programs and activities to be carried out so that they contribute to improving the quality of education.

The most important thing that must be understood is that the objectives of program evaluation must be formulated based on the starting point of the program itself. Program evaluation is conducted to measure the level of program achievement. Information obtained from program evaluations will be very useful for making decisions as material recommendations.

Regarding the follow-up in the quality of education services from the results of interviews with the head of the school, Mr. H. Edi Kiswar, S.Pd, who stated that in following up on the quality of school education services, it must evaluate the school program, follow up after evaluation, if the program does indicate the improvement in the quality of services provided, the program will be eliminated in the future. Evaluation of the work program always coordinates with the headmaster, discussed and concluded so that the principal can take the policy on the existing problems. In addition, the results of the learning process are carried out. All teachers carry out an evaluation of the learning process. Analysis of the evaluation of learning outcomes is carried out at the end of the semester. Evaluation analysis of the results of the learning process is carried out not only based on repetition values but daily results, short-term and longterm projects (student assignments) and daily student behavior and student motor skills. The results of the evaluation of the learning process are contained in $\mathrm{e}$ report cards. School steps for future quality improvement at all times are carried out in all fields, including services provided by schools to study residents, parents, local government, and other external parties. Schools will continue to improve the academic and non-academic values of graduates every year.

Based on the follow-up of the quality of education services in schools, researchers also obtained information with Mr. Sukarsono from the interview results which can be concluded that in carrying out a follow-up on the quality of school education services, the work program evaluation must be carried out once every 3 months by the principal. The results of the 1-year evaluation will be discussed together at the annual meeting and evaluated at the end of each year. Follow-up after evaluation, if the program cannot be continued, it will be off right. Besides doing the results of the learning process, all teachers carry out an evaluation of the learning process. Evaluation analysis of learning outcomes was written at the end of the semester. Evaluation analysis of the results of the learning process is carried out not only based on repetition values but daily results, short-term and longterm projects (student assignments) and daily student behavior and student motor skills. The results of the evaluation of the learning process are contained in $\mathrm{e}$ report cards. School steps for future quality improvement at all times are carried out in all fields, including services provided by schools to study residents, parents, local government, and other external parties. Schools will continue to improve the academic and non-academic values of graduates every year. "

Progress and improvement in education today depends on measuring the results of educational activities and evaluating those measurements based on criteria or certain standards. Measurements try to determine the number of educational outcomes, while assessments try to set prices qualitatively. Likewise, in educational programs, measurement and assessment are used to determine the success of educational activities, in this case, an improvement program. Measurements involve determining the number of changes expected in teaching 
and learning while assessing the price determination of changes or results achieved.

That evaluation of educational programs must cover a broad or comprehensive target area, both its personal aspects, material, and operational aspects. Evaluation Do not only aim at one aspect. For example, the personal aspects, assess not only the teacher but also students, employees, and principals, likewise for the material and operational aspects. The evaluation must be carried out thoroughly.

In evaluating educational supervision, programs must be carried out in collaboration with all people involved in educational program activities. For example, in evaluating the success of teachers in teaching, they must work together between supervisors, principals, teachers themselves, and even with students. By involving all parties in the evaluation of the education program, it is expected to achieve objectivity in evaluating.

The main function of evaluation is to examine an object or state to get the right information as a basis for decision making an evaluation of learning is a process of collecting, analyzing and interpreting information in a systematic manner to determine the extent to which learning objectives are achieved.

To obtain the right information in evaluation activities is carried out through measurement activities. Measurement is a process of giving scores or numbers to a situation or symptom based on certain rules. Thus there is a close relationship between measurement, and evaluation measurement activities are the basis of evaluation activities.

Evaluation is the process of describing, gathering, and presenting information that is useful for consideration in decision making. Learning evaluation is an evaluation in the field of learning. The purpose of learning evaluation is to gather the information that is used as the basis for knowing the level of progress, development, and student learning achievement, as well as the effectiveness of teaching the teacher. Learning evaluation includes measurement and assessment activities. When viewed from the objectives, evaluation of learning is distinguished by diagnostic, selective, placement, formative, and summative evaluations. When viewed from the target, evaluation of learning can be distinguished by evaluating contexts, inputs, processes, results, and outcomes. The evaluation process is carried out through three stages, namely the stages of planning, implementing, processing results, and reporting.

5. Supporting and Inhibiting Factors in the Quality of Educational Services in SMAN 1 Sambas

Quality education is involved from various inputs, such as; teaching materials (cognitive, affective, or psychomotor), methodology (varies according to teacher's ability), school facilities, administrative support and facilities, and other resources as well as creating a conducive atmosphere. School management was class support functions to synchronize various inputs or synergize all components in the interaction (process) of teaching and learning both between teachers, students and supporting facilities in the classroom and outside the classroom; both curricular and extra-curricular contexts, both in the scope of academic and non-academic substance in an atmosphere that supports the learning process.

Through the results of interviews conducted with school principals Mr. H. Edy Kiswar, S.Pd, there are supporting factors and barriers to the quality of education services in schools including the number of students is a supporting factor in improving the quality of services provided to study residents and external schools because of the number of students many can make it easier to get facilities and infrastructure both from government assistance and from students / parents through school committees to support the improvement of activities and teaching-learning processes in schools. Supporting factors in improving the quality of services provided are good cooperation from all parties involved (schools, study residents, government, parents, and school committees). Factors supporting the existence of facilities and infrastructure owned by the school have almost all been fulfilled. All big or small obstacles must all be there, but just how we react to them as principals must be wise.

In addition, the researcher conducted an interview with Ms. Hasibah who provided information about the supporting factors and inhibitors of the quality of education services which came from students such as the implementation of tutoring activities for class XII, students' attendance decreased from year to year which was an effect of IT development need to be present because they can learn and search for information through the facilities they have, even though this activity is free from school. Supporting factors in improving the quality of services provided are good cooperation from all involved and interested. Factors supporting the existence of facilities and infrastructure owned by the school have almost all been fulfilled. The parties involved in supporting the management of the quality of services provided are principals, all teaching staff, noneducational personnel, learning citizens, parents of students, school committees, and local governments. "

One aspect that should get the main attention of every educator manager is about educational facilities. Educational facilities generally include all facilities that are directly used and support the educational process, such as Buildings, study rooms or classes, tools or educational media, tables, chairs, and so on. Whereas what is meant by facilities / infrastructure is that which indirectly supports the course of the education process, such as yard, garden or school park, as well as the road to school.

It cannot be denied that in the education process, the quality of education is also supported by facilities and infrastructure that are the standard of schools or related educational institutions. Facilities and infrastructure greatly affect students' ability to learn. This shows that 
the role of facilities and infrastructure is very important in supporting the quality of student learning. For example, schools in cities that already have computer laboratory facilities, their students can directly learn computers while schools in villages do not have these facilities and do not know how to use computers unless they take courses outside of school.

Management is intended so that the use of facilities and infrastructure in schools can run effectively and efficiently. Management of facilities and infrastructure is a very important activity at school because its existence will greatly support the success of the learning process in school. In managing facilities and infrastructure in schools, a process is needed as it is in existing management in general, namely starting from planning, organizing, mobilizing, maintaining, and controlling.

School is a social institution whose existence is part of the nation's social system that aims to produce human beings who are capable, democratic, responsible, faithful, devoted, physically and mentally healthy, possess knowledge and skills, have a strong and independent personality. In order for these objectives to be achieved, a strong curriculum, both infrastructure, and superstructure are needed. This curriculum will later be used as a guideline in carrying out all learning activities, especially the interaction between educators and students in teaching and learning activities. Teachers as educators are required to be able to organize interesting and meaningful learning so that the achievements achieved can be in accordance with the set targets.

Each subject has a different character from other lessons. Thus, each subject also needs different learning suggestions. In organizing teacher learning certainly requires facilities that can support its performance so that learning can take place attractively. With the support of adequate learning facilities, teachers not only deliver material verbally but also by writing and demonstrating in accordance with the infrastructure provided by the teacher.

Teachers need learning tools to support learning activities. In addition to the ability of teachers to organize learning activities, support from learning facilities is very important in helping teachers. The more complete and adequate learning facilities a school has will make it easier for teachers to carry out their duties as education staff. Similarly, the atmosphere during learning activities. Learning tools must be developed in order to support the teaching and learning process. Yamin mentioned several things that need to be developed in supporting the teaching and learning process: 1) libraries, 2) facilities to support curriculum activities, and 3) infrastructure and facilities for extracurricular activities and local content.

Given the importance of infrastructure in learning activities, students, teachers, and schools will be directly related. Students will be more helped by the support of learning infrastructure. Not all students have a good level of intelligence so that the use of learning infrastructure will help students, especially those who have weaknesses in participating in learning activities. For teachers, they will be helped by supporting infrastructure facilities. Learning activities will also be more varied, interesting, and meaningful. While the school is obliged as the party most responsible for the management of all activities held. In addition to providing, the school also maintains and maintains the infrastructure that it already has.

\section{CONCLUSIONS AND SUGGESTIONS}

\section{A. Conclusions}

After the establishment of research data and discussion obtained a clear picture of the quality of education service management in SMAN 1, the following conclusions are obtained:

1. Quality planning for education services carried out at SMAN 1 Sambas involves various parties in formulating the school's vision and mission so that it reflects and wishes to be desired.

2. The implementation of the quality of educational services carried out at SMAN 1 Sambas also involves various schools in finding solutions if there are various problems that occur.

3. Quality control of educational services carried out in SMAN 1 Sambas is carried out in 2 ways, namely the division of teaching tasks on each teacher's competencies and follow-up evaluation results.

4. Follow-up on the quality of education services carried out in SMAN 1 Sambas is carried out in two ways, namely, evaluation of school programs and evaluation of the results of the learning process.

5. Supporting factors and barriers to the quality of educational services carried out in SMAN 1 Sambas are based on existing facilities and infrastructure in schools.

\section{B. Suggestions}

1. For Principals of SMAN 1 Sambas Referral

The principal needs to conduct a customer satisfaction survey so that the delivery of education services in schools is more intensive and needs to understand the strategies for achieving service quality developed by quality experts.

2. For SMAN 1 Sambas

In improving pedagogical competencies, teachers should not only depend on the programs made by the education service.

3. For researchers at SMAN 1 Sambas later on This research can be used as a reference for researchers from Sambas State High School 1 in the future.

\section{REFERENCES}

Asmara, H. (2017). Educational planning. Pontianak: Fahruna Bahagia Press.

Law of the Government of the Republic of Indonesia Number 20 of 2003 concerning the National Education System. Jakarta: Ministry of National Education. 
Martinus, T. (2016). Building a Quality Management System. Yogyakarta: Leutika Nouvalitera.

Moenir. (2015). Public Service Management in Indonesia. Jakarta: PT Bumi Aksara.

Mustari. (2015). Education Management. Jakarta: PT Raja Grafindo Persada.

Ratminto \& Winarsih. (2016). Service management. Yogyakarta: Student Library.

Sugiyono. (2011). Qualitative and Quantitative Research Methods for $R \& D$. Bandung: Alfabeta.

Supriyanto, A. (2016). Education Service Quality Management. Thesis. Pontianak: University of Tanjung Pura. 